\title{
Pengaruh senam lansia terhadap kadar gula darah pada lansia di BPLU Senja Cerah Manado
}

\author{
${ }^{1}$ Amelia Ramadhani \\ ${ }^{2}$ Ivonny M. Sapulete \\ ${ }^{2}$ Damajanty H. C. Pangemanan
}

\author{
${ }^{1}$ Kandidat Skripsi Fakultas Kedokteran Universitas Sam Ratulangi Manado \\ 2 Bagian Fisiologi Fakultas Kedokteran Universitas Sam Ratulangi Manado \\ Email: amel.rmdhn08@gmail.com
}

\begin{abstract}
Elderly is individuals over 60 years old. Aging in the elderly is a physiological process. Increased blood sugar levels are common among the elderly due to aging and can be prevented by exercising regularly. Elderly gymnastic is a light exercise that can easily be done and not burdensome which applicable to the elderly. The purpose of this study was to determine the effect of elderly gymnastic on blood sugar levels in elderly. This research is an experimental design of the field with one group pre-post test. Respondents are elderly who are living in BPLU Senja Cerah Manado. Blood sampling was done before and after treatment is given. Eighteen respondents were given preferential treatment in the form of elderly gymnastic routine three times a week for eight weeks. The results were tested with Wilcoxon test to determine the effect of elderly gymnastic on fasting glucose levels in elderly before and after treatment. The result showed that average fasting glucose levels was $101.6 \mathrm{mg} / \mathrm{dL}$ and average fasting glucose after treatment was $122,6 \mathrm{mg} / \mathrm{dL}$. There is an effect of elderly gymnastic on blood sugar levels by an increase on blood sugar levels in elderly.
\end{abstract}

Keywords: elderly, exercise, elderly gymnastic, blood sugar

\begin{abstract}
Abstrak: Lansia adalah seseorang dengan usia diatas 60 tahun. Pada lansia terjadi proses penuaan yang merupakan proses fisiologis. Peningkatan kadar gula darah yang umum dialami lansia akibat proses penuaan dapat dicegah dengan berolahraga secara teratur. Senam lansia adalah olahraga ringan yang mudah dilakukan dan tidak memberatkan yang dapat diterapkan pada lansia. Tujuan penelitian ini adalah untuk mengetahui pengaruh senam lansia terhadap kadar gula darah lansia. Penelitian bersifat eksperimental lapangan dengan rancangan pre-post one group test. Responden merupakan lansia di BPLU Senja Cerah Manado. Pengambilan darah dilakukan sebelum dan sesudah diberikan perlakuan. Responden berjumlah 18 orang dan diberikan perlakuan berupa senam lansia secara rutin tiga kali dalam satu minggu selama delapan minggu. Hasil penelitian diuji dengan uji Wilcoxon yang digunakan untuk menentukan pengaruh senam lansia terhadap kadar gula darah puasa, sebelum dan sesudah perlakukan. Hasil menunjukkan bahwa rerata kadar gula darah puasa sebelum senam lansia adalah 101,6 mg/dL dan kadar gula darah puasa setelah senam lansia adalah 122,6 mg/dL. Ada pengaruh senam lansia terhadap kadar gula darah berupa peningkatan kadar gula darah pada lansia.
\end{abstract}

Kata kunci: lansia, olahraga, senam lansia, gula darah

Keberhasilan pembangunan di berbagai bidang terutama di bidang kesehatan menyebabkan terjadinya peningkatan usia harapan hidup penduduk dunia termasuk 
Indonesia. Menurut Undang-undang Republik Indonesia Nomor 13 tahun 1998 tentang Kesejahteraan Lanjut Usia yang dimaksud dengan Lanjut Usia (Lansia) adalah seseorang yang telah mencapai usia 60 tahun ke atas. Berdasarkan Pusat Data dan Informasi dari Kementerian Kesehatan RI, proporsi penduduk lansia di Indonesia pada tahun 2012 sebesar 7,59\%. Jumlah lansia perempuan (10.046.073 jiwa atau 54\%) lebih banyak daripada lansia laki-laki (8.538.832 jiwa atau 46\%). Adanya kecenderungan peningkatan persentase kelompok lansia dibandingkan dengan kelompok usia lainnya yang cukup pesat sejak tahun 2013 (8,9\% di Indonesia dan 13,4\% di dunia) hingga tahun 2050 (21,4\% di Indonesia dan 25,3\% di dunia) dan 2100 (41\% di Indonesia dan 35,1\% di dunia). ${ }^{1}$

Proses penuaan merupakan tantangan yang harus ditanggulangi karena diartikan dengan proses kemunduran prestasi kerja dan penurunan kapasitas fisik seseorang. Akibatnya kaum lansia menjadi kurang produktif, rentan terhadap penyakit dan banyak bergantung pada orang lain. Ketidakaktifan secara fisik dapat mengakibatkan buruknya profil serum lipoprotein dan meningkatnya resistensi insulin perifer. Hal-hal tersebut merupakan faktor risiko dari penyakit kardiovaskuler, obesitas, hipertensi, intoleransi glukosa dan diabetes mellitus tipe dua. Olahraga aerobik seperti senam dapat memperlambat proses kemunduran dan penurunan kapasitas tersebut selain itu juga dapat menurunkan kadar gula darah puasa, meningkatkan ketahanan sistem kardiorespirasi serta memperbaiki komposisi lemak dan tubuh karena pada dasarnya olahraga dapat mempertahankan fungsi dari sistem muskuloskeletal (otot dan tulang) serta sistem kardiopulmonar (jantung dan paru-paru). ${ }^{2,3}$

Olahraga adalah serangkaian gerak raga yang teratur dan terencana yang dilakukan orang dengan sadar untuk meningkatkan kemampuan fungsionalnya. Olahraga merupakan bagian dari latihan fisik yang direncanakan, terstruktur, dan dilakukan berulang-ulang serta bertujuan untuk perbaikan atau pemeliharaan kebugaran fisik. ${ }^{4}$

Senam lansia adalah olahraga ringan yang mudah dilakukan dan tidak memberatkan yang dapat diterapkan pada lansia. Senam lansia merupakan program Menteri Kepemudaan dan Olahraga yang bertujuan untuk mengupayakan peningkatan kesegaran jasmani kelompok lansia yang jumlahnya semakin bertambah. Senam lansia ini dirancang khusus untuk membantu lansia agar dapat mencapai usia lanjut yang sehat, berguna, bahagia dan sejahtera. ${ }^{5,6}$

Penelitian dilakukan oleh Hairani, dkk mengenai perbedaan kadar gula darah pada lansia penderita diabetes mellitus tipe dua yang melakukan senam lansia. Hasilnya terdapat penurunan yang signifikan pada kadar gula darah responden. ${ }^{7}$ Selama olahraga sel otot menggunakan lebih banyak glukosa dan bahan bakar nutrien lain dibandingkan biasanya untuk menjalankan aktivitas kontraktil. Glukosa atau disebut juga gula darah adalah monosakarida dan zat metabolit primer untuk produksi energi dalam tubuh dalam bentuk ATP. Ketika berolahraga dibutuhkan energi yang cukup hingga terjadi pemecahan glukosa menjadi ATP yang mengakibatkan berkurangnya kadar gula darah dalam tubuh. ${ }^{8}$ Kadar gula darah yang berlebihan atau kekurangan akan menimbulkan masalah kesehatan pada tubuh. Pada penelitian ini lansia diajak untuk melakukan senam lansia untuk melihat efeknya pada kadar gula darah.

\section{METODE PENELITIAN}

Jenis penelitian bersifat eksperimental lapangan dengan rancangan pre-post one group test. Penelitian ini dilakukan pada bulan Oktober 2015 sampai Desember 2015 di BPLU Senja Cerah, Paniki Bawah, Manado. Populasi penelitian ini adalah semua lansia di BPLU Senja Cerah. Responden penelitian diambil dari sebagian populasi yang memenuhi kriteria inklusi seperti usia 60 tahun keatas, dapat diberi 
latihan fisik, dan bersedia mengikuti penelitian.

Definisi operasional lansia adalah lansia yang berusia 60 tahun keatas di BPLU Senja Cerah Manado. Kadar glukosa darah puasa responden yang diukur menggunakan alat autocheck Nesco dengan satuan $\mathrm{mg} / \mathrm{dL}$ diambil sebelum dan sesudah dilakukan senam lansia selama delapan minggu. Nilai normal glukosa puasa $<100$ $\mathrm{mg} / \mathrm{dL}$. Senam lansia yang dilakukan tiga kali dalam seminggu selama delapan minggu. Satu sesi berlangsung selama 15 menit pemanasan, 30 menit inti, 15 menit pendinginan.

\section{HASIL PENELITIAN}

Penelitian mengenai pengaruh senam lansia terhadap kadar gula darah puasa dilakukan di BPLU Senja Cerah Manado pada bulan Oktober 2015 sampai Desember 2015. Responden merupakan total populasi yang memenuhi kriteria inklusi berjumlah 34 orang. 16 orang dieksklusi karena tidak mengikuti keseluruhan prosedur penelitian. Berikut ini akan diuraikan hasil penelitian dalam bentuk tabel, diagram dan penjelasan.

Tabel 1. Distribusi frekuensi responden berdasarkan jenis kelamin

\begin{tabular}{lcc}
\hline Jenis Kelamin & F & P (\%) \\
\hline Perempuan & 11 & 61,1 \\
Laki-laki & 7 & 38,9 \\
\hline
\end{tabular}

$\mathrm{F}=$ Frekuensi $\mathrm{P}=$ Persentase

Berdasarkan jumlah total responden sebanyak 18 orang, 11 diantaranya merupakan perempuan (61,1\%) dan lakilaki sebanyak 7 (38,9\%).

Tabel 2. Distribusi frekuensi responden berdasarkan usia

\begin{tabular}{lcc}
\hline Kelompok Usia & F & P (\%) \\
\hline Elderly & 10 & 55,6 \\
Old & 8 & 44,4 \\
\hline
\end{tabular}

$\mathrm{F}=$ Frekuensi $\mathrm{P}=$ Persentase
Karakteristik responden dibagi sesuai usia menurut ketetapan dari WHO. Lanjut usia (elderly) dengan rentang usia antara 60 - 74 tahun terdapat 10 orang (55,6\%). Delapan orang yang tergolong lanjut usia tua (old) dengan rentang usia antara 75 90 tahun $(44,4 \%)$.

Tabel 3. Distribusi responden pre dan post test sesuai kadar GDP

\begin{tabular}{lcccc}
\hline \multicolumn{1}{c}{ GDP } & \multicolumn{2}{c}{ Pre-test } & \multicolumn{2}{c}{ Post-test } \\
\cline { 2 - 5 } & $\mathrm{n}$ & $\%$ & $\mathrm{n}$ & $\%$ \\
Hipoglikemik & 3 & 16,7 & 0 & 0 \\
Normal & 4 & 22,2 & 1 & 5,6 \\
Terganggu & 0 & 0 & 4 & 22,2 \\
Hiperglikemik & 11 & 61,1 & 13 & 72,2 \\
\hline
\end{tabular}

Berdasarkan Tabel 3, pada pemeriksaan sebelum dilakukan senam lansia sebanyak tiga orang responden termasuk hipoglikemia dengan kadar gula darah puasa $<70 \mathrm{mg} / \mathrm{dL}$. Setelah dilakukan senam lansia, tidak didapatkan lagi responden yang hipoglikemia. Empat orang responden sebelum senam lansia berada pada rentang gula darah puasa normal yaitu antara $70-90 \mathrm{mg} / \mathrm{dL}$ yang kemudian menurun jumlahnya setelah senam lansia menjadi satu orang. Gula darah puasa terganggu dengan rentang $90-99 \mathrm{mg} / \mathrm{dL}$ didapatkan pada empat orang responden setelah dilakukan senam. Hiperglikemia dengan kadar gula darah puasa $>100 \mathrm{mg} / \mathrm{dL}$ didapatkan pada 11 orang responden sebelum dilakukan senam lalu jumlahnya meningkat jadi 13 orang setelah senam.

Tabel 4. Rerata Kadar Gula Darah Puasa Dengan Uji Wilcoxon

\begin{tabular}{lcc}
\hline & $\begin{array}{l}\text { Rerata } \\
\text { (mg/dL) }\end{array}$ & p \\
\hline $\begin{array}{l}\text { GDP pre- } \\
\text { test }\end{array}$ & 101,6 & 0,02 \\
$\begin{array}{l}\text { GDP post- } \\
\text { test }\end{array}$ & 122,6 & \\
\hline
\end{tabular}

Pada Tabel 2, terlihat bahwa selisih kadar gula darah puasa sebelum dan 
sesudah senam lansia menunjukkan perbedaan yang bermakna secara statistik dengan $\mathrm{p}=0,048$.

\section{BAHASAN}

Pada pemeriksaan awal ditemukan tiga orang lansia mengalami hipoglikemik namun setelah dilakukan senam jumlah lansia yang hipoglikemik menjadi tidak ada. Selanjutnya lansia dengan kadar gula darah puasa normal menurun jumlahnya dari empat orang menjadi satu orang sedangkan lansia dengan gula darah puasa terganggu ditemukan pada empat orang setelah senam. Lansia dengan hiperglikemik meningkat jumlahnya menjadi 13 orang dari yang awalnya 11 orang.

Tiga orang responden yang ditemukan hipoglikemia pada pemeriksaan awal mungkin diakibatkan keadaan responden yang berpuasa terlalu lama. Hal ini terkait dengan pengambilan darah awal membutuhkan waktu yang lebih lama dibandingkan dengan pengambilan darah akhir. Pada orang dewasa normal, ketika berpuasa lebih dari delapan jam dibutuhkan mekanisme dasar pertahanan fisiologis yang melibatkan peran berbagai hormon seperti insulin, glukagon, dan katekolamin agar terjadi keseimbangan kadar glukosa di darah dan mencegah terjadinya hipoglikemik. ${ }^{9}$ Moebus, dkk memaparkan semakin memburuknya metabolisme glukosa seiring dengan bertambahnya usia dapat mengganggu proses untuk mencapai homeostasis glukosa dan mengakibatkan terjadinya hipoglikemik. Selain itu keadaan hipoglikemia akibat berpuasa dapat disebabkan penyakit yang diderita dan kebiasaan mengonsumsi obat-obatan atau herbal tertentu serta alcohol. ${ }^{10}$

Terjadinya peningkatan rerata gula darah puasa dan meningkatnya jumlah lansia yang mengalami hiperglikemia mungkin disebabkan tidak patuhnya lansia ketika melakukan senam lansia. Beberapa lansia ketika senam tidak mencapai waktu 60 menit, sebagian lain tidak mengikuti gerakan senam seperti yang diinstruksikan akibat kelelahan. Tidak maksimalnya senam lansia yang dilakukan berakibat tidak tercapainya efek senam lansia pada tubuh yaitu penurunan kadar gula darah puasa.

Faktor usia juga berpengaruh terhadap terjadinya hiperglikemia. Seiring dengan bertambahnya usia kadar gula darah puasa juga akan meningkat. Penyebabnya multifaktorial, salah satunya adalah menurunnya sensitivitas insulin serta berkurangnya jumlah sel islet pankreas. ${ }^{11,12}$

Kirkman, dkk mengatakan bahwa resistensi insulin yang berkaitan dengan usia secara utama berhubungan dengan penumpukan jaringan lemak, sarkopenia, dan berkurangnya aktifitas fisik. Sarkopenia adalah hilangnya massa otot yang sering dialami lansia. Otot rangka, yang merupakan jaringan utama dalam metabolisme glukosa, menurun ukuran serta kekuatannya sehingga mengakibatkan kelemahan otot dan berkurangnya aktifitas fisik. Hal-hal tersebut menyebabkan berkurangnya pemakaian energi dan menumpuknya jaringan lemak hingga menyebabkan resistensi insulin. Meningkatnya penumpukan jaringan lemak dapat menurunkan pembentukan glikogen di otot rangka yang dimediasi insulin. ${ }^{11}$

Pada penelitian ini juga peneliti tidak dapat mengontrol pola diet dan gaya hidup para responden. Pengambilan darah akhir ketika itu dilakukan pada waktu yang dekat dengan perayaan hari besar. Perayaan ini identik dengan konsumsi makanan dan minuman dalam jumlah besar yang tidak dapat dikontrol. Menurut Fowler, selain berolahraga, pengaturan diet berupa batasan asupan kalori sebanyak 1.100 $\mathrm{kcal} / \mathrm{hari}$ selama empat hari dapat menurunkan kadar gula darah puasa. Hal ini disebabkan berkurangnya produksi gula darah dari hepar. Setelah penelitian dilakukan selama 28 hari, kadar gula darah puasa semakin menurun dan diiringi dengan peningkatan sensitivitas insulin. ${ }^{13}$

Tidak berbeda halnya dengan penelitian oleh Behboudi, dkk berupa olahraga sebanyak tiga kali seminggu 
selama delapan minggu yang menghasilkan efek tidak signifikan terhadap perubahan kadar gula darah puasa. Dinyatakan bahwa pengambilan glukosa oleh otot rangka (glucose uptake) dapat berlangsung selama 48 jam setelah satu sesi olahraga. Hal ini dapat disebabkan karena meningkatnya sensitivitas insulin dan juga pengaruh dari endogen yaitu meningkatnya pembawa GLUT di sarkolema pada filamen otot. Peningkatan sensitivitas insulin dapat bertambah jika semakin banyak otot pada tubuh yang terlibat ketika berolahraga namun jika hal ini dilakukan oleh responden yang tidak biasa berolahraga maka dapat menimbulkan cedera otot. Jika cedera otot terjadi maka pengikatan insulin oleh reseptornya di otot akan menurun pada waktu yang singkat sehingga pengambilan glukosa oleh otot tidak akan maksimal. Dipaparkan bahwa keterbatasan penelitian ini yaitu peneliti tidak dapat mengontrol konsumsi makanan dan gaya hidup responden secara total. ${ }^{14}$

Penelitian oleh Tetty, dkk terhadap 20 orang lansia diabetes untuk melihat pengaruh senam terhadap kadar glukosa darah. Pada penelitian ini didapatkan hasil yang signifikan berupa penurunan kadar gula darah. Selain itu disimpulkan juga untuk mencapai regulasi insulin maksimal dibutuhkan pengaturan diet, pola makan, konsumsi obat serta olahraga secara teratur. ${ }^{15,16}$

Tan, dkk melakukan penelitian terhadap 30 orang lansia dengan melakukan senam gabungan antara aerobik dan resistance selama enam bulan. Hasilnya terjadi penurunan kadar gula darah puasa pada kelompok olahraga, sedangkan pada kelompok kontrol terjadi peningkatan kadar gula darah puasa. ${ }^{17}$ Penelitian ini berlangsung lebih lama dari yang peneliti lakukan, yaitu selama enam bulan. Olahraga yang dilakukan juga lebih beragam dan intens dengan menggunakan olahraga gabungan antara aerobik dan resistance hingga dapat menghasilkan penurunan kadar gula darah puasa secara signifikan.
Hairani, dkk menyatakan bahwa otot yang sedang berkontraksi ketika berolahraga memiliki sifat seperti insulin (insulin-like effect). Permeabilitas membran terhadap glukosa meningkat pada otot yang berkontraksi. Saat berolahraga resistensi insulin berkurang, sebaliknya sensitivitas insulin meningkat karena terjadi peningkatan afinitas (kekuatan menarik) dan jumlah tempat reseptor di membran yang secara spesifik mengikat insulin. Respons ini hanya terjadi setiap kali berolahraga, bukan merupakan efek yang menetap atau berlangsung lama, oleh karena itu berolahraga harus dilakukan secara teratur. ${ }^{7}$

\section{SIMPULAN DAN SARAN}

Berdasarkan hasil penelitian dan pembahasan, maka dapat disimpulkan bahwa senam lansia berpengaruh terhadap kadar gula darah puasa $(\mathrm{p}=0,048<\mathrm{p}=$ 0.05). Senam lansia perlu dilakukan dengan frekuensi lebih dari tiga kali setiap minggu selama delapan minggu dan secara berkelanjutan serta teratur. Untuk penelitian berikutnya dapat dilakukan penelitian yang lebih lama dengan ditambah kelompok kontrol dan juga mengontrol pola diet serta gaya hidup responden. Sebaiknya dilakukan juga wawancara mengenai riwayat penyakit keluarga responden.

\section{DAFTAR PUSTAKA}

1. Pusat Data dan Informasi Kementerian Kesehatan RI. Situasi dan analisis lanjut usia. 29 Mei 2014 [diakses pada 2015 September 24]. Tersedia dari:

http://www.depkes.go.id/resources/do wnload/pusdatin/infodatin/infodatinlansia.pdf

2. Kadir A. Olahraga pada lanjut usia (Lansia). Wijaya Kusuma. 2007;1:6368.

3. Asiehsadat M, Saeed S, Gholamhassan J, Hassan D. 2013. Comparing effects of 12 weeks walking and selected aerobic exercise on fasting and twohour blood glucose in inactive 
postmenopausal women. International Journal of Sport Studies. 3(9). 91917.

4. Pink B. Defining sport and physical activity. Australian Bureau of Statistics. 2008.

5. Novarina V. Hubungan dukungan keluarga tentang senam lansia dengan keaktifan mengikuti senam di posyandu "Peduli Insani" di Mendungan Desa Pabelan Kartasura. [skripsi]. [Surakarta] : Universitas Muhamadiyah Surakarta;2012.

6. Tegawati LM, Karini SM, Agustin RW. Pengaruh senam lansia terhadap penurunan tingkat depresi pada orang lanjut usia. Psikologi FK UNS. 2009:36-45.

7. Hairani D. Pengaruh senam lansia terhadap kadar glukosa darah pada penderita diabetes mellitus tipe 2. STIKES Semarang. 2014.

8. Guyton AC, Hall JE. Fisiologi kedokteran. Edisi 6. Jakarta: EGC. 2012.

9. Al-Arouj, M. Assaad-Khalil S, Buse J, Fahdil I, Fahmy M, Hafez S, dkk. Recommendations for management of diabetes during Ramadhan. Diabetes Care. 2010;33(8):1895-1902.

10.Moebus S, Gores L, Losch C, Jockel KH. Impact of time since last calorie intake on blood glucose levels. Eur J
Epidemiol. 2011;26:719-28.

11.Kirkman MS, Briscoe VJ, Clark N, Florez H, Haas LB, Halter JB, dkk. Diabetes in older adults. Diabetes Care. 2012;35:2650-64.

12.Ko GT, Wai HPS, Tang JSF. Effects of age on plasma glucose levels in nondiabetic Hongkong Chinese. Croat Med J. 2006;47:709-13.

13.Fowler MJ. Diabetes treatment, part 1: diet and exercise. Diabetes Foundation. 2007;25(3):105-9.

14.Behboudi L, Azarbayjani MA, Aghaalinejad H, Salavati M. Effect of aerobic exercise and whole body vibration on glycaemia control in type 2 diabetic males. Asian Journal of Sports Medicine. 2011;2(2):83-90.

15.Straser B, Schobersberger W. Evidence for resistance training as a treatment therapy in obesity. Journal of obesity. 2010;2011.

16.Aritonang TR. Pengaruh senam diabetes terhadap penurunan kadar gula darah. Bekasi. 2014.

17.Tan S, Li W, Wang J. Effect of six months of combined aeorobic and resistance training for elderly patients with a long history of type 2 diabetes. Journal of Sports Science and Medicine. 2012;11:495-501. 